Original Research Paper

\title{
Optimalisasi Pemanfaatan Limbah Rumah Tangga sebagai Bahan Pupuk Organik Cair untuk Menumbuhkan Sikap dan Perilaku Peduli Lingkungan pada Siswa MTs. Haudhul Ulum Gegutu Telaga
}

\author{
Ayudya Lestari $^{1 *}$, Annisa Zikri Robbia ${ }^{1}$, Lalu Raftha Patech ${ }^{1}$, Abdul Syukur $^{1}$ \\ ${ }^{\text {I} P r o g r a m ~ S t u d i ~ M a g i s t e r ~ P e n d i d i k a n ~ I P A, ~ F a k u l t a s ~ P a s c a s a r j a n a, ~ U n i v e r s i t a s ~ M a t a r a m, M a t a r a m, ~ I n d o n e s i a ~}$
}

https://doi.org/10.29303/jpmpi.v3i2.656

Sitasi: Lestari, A., Robbia, A. Z., Patech, L. R., \& Syukur, A. (2021). Optimalisasi Pemanfaatan Limbah Rumah Tangga sebagai Bahan Pupuk Organik Cair untuk Menumbuhkan Sikap dan Perilaku Peduli Lingkungan pada Siswa MTs. Haudhul Ulum Gegutu Telaga. Jurnal Pengabdian Magister Pendidikan IPA, 4(1)

\author{
Article history \\ Received: 03 Februari 2021 \\ Revised: 08 Maret 2021 \\ Accepted: 06 April 2021 \\ *Corresponding Author: \\ Ayudya Lestari, Program Studi \\ Magister Pendidikan IPA, \\ Fakultas Pascasarjana, \\ Universitas Mataram,Mataram, \\ Indonesia; \\ Email: \\ ayudya3800@gmail.com
}

\begin{abstract}
Aktivitas rumah tangga yang tidak dikelola dengan bijak dan berakhir di tempat pembuangan sampah sering kali menimbulkan dampak terhadap beberapa aspek kehidupan, diantaranya aspek kesehatan, aspek lingkungan, dan aspek estetika. Sikap dan kepedulian masyarakat terhadap sampah menjadi perhatian dan tanggung jawab setiap lapisan masyarakat dalam menjaga dan melestarikan lingkungan alam sekitar. Tujuan pengabdian ini salah satunya adalah mengenalkan pemanfaatan sampah yang mudah dan dapat dilakukan oleh masyarakat dan siswa sekolah MTs Haudhul Ulum Gegutu Telaga yang menjadi target luaran dengan cara fermentasi karena teknologi yang digunakan sangat sederhana dan biaya penanganan yang murah yaitu pengolahan limbah rumah tangga untuk menghasilkan Mikroorganisme Lokal (MOL) menjadi Pupuk Organik Cair (POC) dari limbah Nasi (Oryza sativa). Adapun metode yang digunakan dalam pelaksanaan kegiatan pengabdian yaitu sosialisasi, pelatihan, dan penilaian sikap dan perilaku peduli lingkungan. Pengabdian POC ini dapat menghasilkan Pupuk Organik Cair yang bagus sesuai dengan kriteria dan juga melalui kegiatan pengelolaan limbah rumah tangga menjadi POC, diketahui siswa/i MTs. Haudhul Ulum memiliki sikap peduli lingkungan yang baik $(89,5 \%)$ dan perilaku peduli lingkungan yang cukup baik $(72,9 \%)$. Dengan demikian, dapat disimpulkan bahwa dengan memberikan edukasi dan pelatihan kepada siswa mengenai cara mengolah sampah dengan bijak dapat menumbuhkan bahkan meningkatkan sikap dan perilaku peduli lingkungan.
\end{abstract}

Keywords: Limbah; MOL; POC; nasi; Sikap dan Perilaku Peduli Lingkungan.

yang belum memanfaatkan sampah organik menjadi kompos. Secara umum, masih banyak ditemukan produksi limbah rumah tangga yang tidak dikelola dengan bijak dan berakhir di tempat pembuangan sampah. Sering kali ditemukan limbah rumah tangga yang dibuang dengan sengaja ke selokan atau sungai sekitar dan menimbulkan dampak terhadap beberapa aspek kehidupan, diantaranya aspek kesehatan, aspek lingkungan, dan aspek estetika. Sikap dan kepedulian masyarakat 
terhadap sampah masih sangat kurang, sehingga hal ini menjadi perhatian dan tanggung jawab setiap lapisan masyarakat dalam menjaga dan melestarikan lingkungan alam sekitar.

Semua proses kehidupan yang ada pasti menghasilkan limbah. Jumlah limbah dan jenisnya akan terus bertambah seiring dengan bertambah nya jumlah penduduk (Mulyono. 2016). Hal ini dapat diatasi dengan cara mengolahnya. Konsep yang dapat digunakan untuk pengolahan limbah buangan adalah dengan cara $3 \mathrm{R}$ yaitu recycle (memodifikasi benda yang sebelumnya tidak bermanfaat menjadi benda yang bermanfaat), reduse (menggurangi penggunaan produk yang menghasilkan sampah), reuse (menggunakan ulang barang yang akan menghasilkan sampah) (Nisa, 2016).

Sampah pada dasarnya merupakan suatu bahan yang terbuang dari suatu sumber hasil aktivitas manusia maupun proses-proses alam yang tidak mempunyai nilai ekonomi, bahkan dapat mempunyai nilai yang negatif karena penanganannya, baik untuk membuang atau membersihkannya memerlukan biaya yang cukup besar. Sampah dan pengelolaannya kini menjadi hal yang mendesak sebab apabila tidak dilakukan penanganan yang baik akan menyebabkan hal yang tidak diharapkan sehingga dapat mencemari lingkungan (Sunarsih, 2018). Oleh karena itu, diperlukan pengendalian dan pengolahan sampah yang tepat terutama sampah organik. Salah satu pemanfaatan sampah organik yang mudah dan dapat dilakukan oleh masyarakat dan siswa sekolah yang menjadi target luaran adalah dengan cara fermentasi karena teknologi yang digunakan sangat sederhana dan biaya penanganan yang murah yaitu pengolahan limbah rumah tangga untuk menghasilkan Mikroorganisme Lokal (MOL).

MOL adalah mikroorganisme lokal, yaitu sekumpulan mikroorganisme yang berfungsi sebagai pupuk organik cair, starter dalam pembuatan kompos organik dengan kata lain MOL akan mempercepat proses pengomposan dan sebagai dekomposer yang akan mempercepat penguraian senyawa-senyawa organik. MOL dapat dibuat dengan sangat sederhana yakni dapat memanfaatkan limbah dari rumah tangga atau memanfaatkan sisa dari tanaman, buah-buahan, kotoran hewan, nasi basi, bonggol pisang dan lain sebagainya (Kochakinezhad et al., 2012).

Peningkatan kesadaran dan kepedulian terhadap limbah rumah tangga tersebut dilakukan dengan cara memanfaatkan limbah menjadi pupuk organik cair (POC) dengan tujuan mengurangi sampah yang tidak termanfaatkan. Pupuk organik cair (POC) merupakan hasil fermentasi yang terjadi karena perubahan enzimatik secara anaerob dari suatu senyawa organik menjadi produk organik yang lebih sederhana. Hal ini merupakan salah satu bentuk pemanfaatan bioteknologi dalam pengelolaan limbah dan lingkungan. Manfaat dari POC diantaranya dapat mendorong dan meningkatkan pembentukan klorofil daun dan pembentukan bintil akar pada tanaman kacangkacangan dalam upaya memaksimalkan penyerapan nitrogen dari udara. Penggunaan alat dan bahan pupuk organik cair (POC) ini pun dirasa cukup ekonomis dan dapat dijangkau oleh setiap kalangan masyarakat. MOL nasi basi digunakan dalam penelitian ini dengan pertimbangan setiap rumah tangga mengkonsumsi nasi,yang sedikit banyaknya pasti ada yang tersisa. Hal inilah yang melatar belakangi untuk membut MOL. Jenis mikroba yang terkandung dalam MOL nasi basi adalah Sachharomyces cerevicia dan Aspergillus sp yang berperan dalam proses pengomposan.

Pembuatan POC dengan memanfaatkan limbah rumah tangga berpotensi untuk meningkatkan produktifitas tanaman dan alternatif pilihan dalam mengurangi produksi limbah rumah tangga. Alternatif dari pengolahan limbah tersebut diyakini dapat menjadi solusi dalam menumbuhkan kesadaran akan sikap dan perilaku peduli lingkungan seperti yang ada dalam materi pembelajaran kelas $7 \mathrm{Bab}$ materi Pencemaran Lingkungan subbab Daur ulang terutama dari kalangan siswa dan siswi MTs. Haudhul Ulum Gegutu. Selain itu dari program ini dihasilkan publikasi pada jurnal yang memiliki akreditasi Nasional dan brosur untuk pengolahan Pupuk Orgaanik Cair (POC) dari Mikroorganisme Lokal (MOL) Nasi Basi (Oryza sativa).

Kelompok sasaran dalam program pengabdian ini adalah siswa dan siswi MTs. Haudhul Ulum. Adapun hasil analisis permasalahan dapat dirumuskan sebagai berikut:

1. Masyarakat Dusun Gegutu Telaga lebih tepatnya siswa dan siswi MTs. Haudhul Ulum belum memahami cara mengolah limbah rumah tangga yang baik dan benar.

2. Kurangnya pengetahuan dan pemahaman dalam memperlakukan limbah rumah tangga sehingga 
pengetahuan yang dipelajari siswa dan siswi

MTs. Haudhul Ulum menjadi kurang bermakna. Solusi relevan dari permasalahan di atas ialah memberikan edukasi dalam mengelola limbah rumah tangga menjadi pupuk organik cair (POC), dan Mengadakan praktik langsung mengenai cara pembuatan pupuk organik cair (POC) kepada siswa dan siswi MTs. Haudhul Ulum Gegutu dalam menumbuhkan sikap dan perilaku peduli lingkungan. Adapun target luaran dalam kegiatan pengabdian ini ialah Siswa dan siswi MTs.Haudhul Ulum Gegutu memiliki pengalaman belajar mengenai cara mengelola limbah rumah tangga dengan baik dan benar. Diharapkan dapat menjadi salah satu upaya/bentuk usaha dalam mengurangi jumlah produksi limbah rumah tangga di kawasan Gegutu Telaga. Selain itu dari program ini dihasilkan Publikasi pada jurnal yang memiliki akreditasi Nasional dan brosur untuk pengolahan Pupuk Orgaanik Cair (POC) dari Mikroorganisme Lokal (MOL) Nasi Basi (Oryza sativa).

\section{Metode}

Persiapan kegiatan pengabdian kepada siswa dan siswi MTs.Haudhul Ulum dalam pengelolaan limbah rumah tangga menjadi pupuk organik cair (POC) dimulai dari tahap persiapan materi, mengurus surat izin pengabdian, konsolidasi dengan Kepala MTs Haudhul Ulum, dan persiapan lokasi kegiatan pengabdian.

Adapun metode yang digunakan dalam pelaksanaan kegiatan pengabdian sebagai berikut:

a. Sosialisasi: Pemberian edukasi kepada siswa dan siswi MTs.Haudhul Ulum bahwa limbah rumah tangga yang sering kali dibuang tanpa dikelola dengan bijak nyatanya dalam diolah sedemikan rupa menjadi pupuk organik cair yang kaya akan manfaat bagi pertumbuhan dan perkembangan tumbuhan.

b. Pelatihan: Menggunakan metode unjuk kerja atau praktik langsung pembuatan pupuk organik cari (POC) dari limbah rumah tangga.

c. Penilaian: Melakukan penilaian sikap dan perilaku peduli lingkungan siswa dan siswi MTs.Haudhul Ulum menggunakan angket penilaian.
Metode yang digunakan pada praktikum Pertanian Organik dengan materi pembuatan mikroorganisme lokal (MOL) yaitu nasi dijamurkan sampai terdapat warna oranye, kemudian dicampurkan dengan larutan gula dengan komposisi satu liter air untuk lima sendok makan gula. Nasi dimasukkan dengan cara diremas-remas sedikit demi sedikit hingga halus. Campuran nasi yang berjamur dengan larutan gula diaduk dalam ember dan dibiarkan selama satu minggu hingga berbau seperti tapai. MOL kemudian siap digunakan sebagai starter kompos, dilarutkan kembali dengan air dengan perbandingan 1:5. MOL yang telah dilarutkan dengan air dipindahkan ke dalam botol agar tertutup dan tidak tumpah.

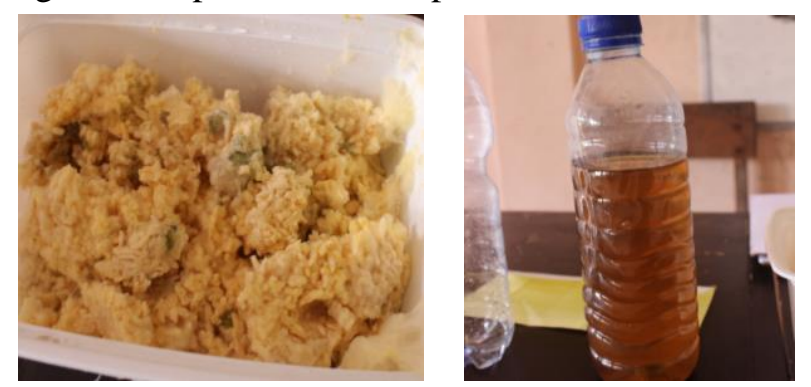

Gambar 1. Nasi Basi dan Larutan Gula Merah

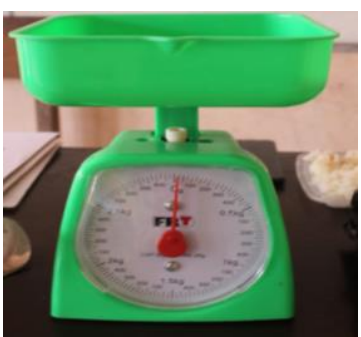

Gambar 2. Timbangan

Teknik pengumpulan data sikap dan perilaku peduli lingkungan menggunakan angket penilaian sikap dan perilaku peduli lingkungan. Hasil skor perolehan siswa selanjutnya dianalisis secara deskriptif dan dikualifikasikan berdasarkan kategori sikap dan perilaku penduli lingkungan.

\section{Hasil dan Pembahasan}

\section{Edukasi dan Pelatihan Tentang Pupuk Organik Cair (POC)}

Secara umum proses edukasi pada kegiatan ini meliputi beberapa pemahaman diantaranya mengenai dampak negatif limbah rumah tangga, pentingnya mengolah limbah rumah tangga, 
pembuatan POC sebagai salah satu upaya mengelola limbah rumah tangga, dan manfaat dari POC bagi tanaman. Hal terpenting pada proses edukasi ini adalah siswa dapat menumbuhkan sikap dan perilaku peduli lingkungan. Sehingga apa yang dipelajari menjadi lebih bermakna dan bermanfaat bagi diri sendiri dan juga lingkungan.

Pupuk Organik Cair (POC) merupakan pupuk yang dapat memberikan hara sesuai dengan kebutuhan tanaman. Sehingga apabila tanaman diberikan pupuk cair dengan jumlah yang banyak, tanaman akan dengan mudah mengatur penyerapannya sesuai kebutuhan. Dengan demikian, dalam mengaplikasikan pupuk organik cair penting untuk memperhatikan besarnya konsentrasi pupuk. Jenis POC bermacam-macam, salah satunya adalah molekul organisme lokal (MOL). MOL adalah sekumpulan mikroorganisme lokal yang berfungsi sebagai POC. Starter dalam pembuatan kompos organik dengan kata lain MOL akan mempercepat proses pengomposan dan mempercepat penguraian senyawa-senyawa organik oleh dekomposer. POC sendiri memiliki beberapa keuntungan diantaranya mudah diaplikasikan, unsur hara yang terdapat pada POC mudah diserap oleh tanaman, serta mengandung mikroorganisme yang jarang terdapat pada pupuk organik padat (Masluki et al, 2016).

Peduli lingkungan merupakan salah satu pendidikan karakter yang erat kaitannya dengan psikis individu. Melalui pendidikan karakter siswa akan lebih memaknai sudut pandang terhadap nilainilai kehidupan, seperti kejujuran, tanggung jawab, dan kepedulian. Peduli lingkungan merupakan suatu sikap dan tindakan dalam upaya mencegah serta memperbaiki kerusakan lingkungan alam yang terjadi. Pendidikan karakter peduli lingkungan di sekolah pada dasarnya dapat membantu guru dalam penanaman karakter siswa tentang kepedulian mereka terhadap lingkungan sekitar (Purwanti, 2017). Manfaat dalam mengajarkan siswa peduli lingkungan, diantaranya siswa menjadi lebih bertanggung jawab terhadap lingkungannya dan segala tindakan yang dilakukan. Selain itu, siswa lebih berhati-hati dalam bertindak dan mengambil keputusan sebab siswa tidak lagi memikirkan dirinya sendiri melainkan orang lain dan juga lingkungan. Adapun hasil pengukuran terhadap sikap dan perilaku peduli lingkungan siswa/i MTs. Haudhul Ulum disajikan pada Tabel 1.
Tabel 1. Sikap dan Perilaku Peduli Lingkungan MTs. Haudhul Ulum

\begin{tabular}{clcc}
\hline No & Aspek Penilaian & Rata-Rata & Kategori \\
\hline 1 & Sikap & 89,5 & Baik \\
2 & Perilaku & 72,9 & Sedang \\
\hline
\end{tabular}

Berdasarakan Tabel 1 diketahui bahwa rata-rata skor sikap peduli lingkungan sebesar 89,5 dengan kategori baik. Sementara itu, rata-rata skor perilaku peduli lingkungan sebesar 72,9 dengan kategori sedang. Dengan demikian, pencapaian oleh siswa/i MTs. Haudhul Ulum dapat memberikan gambaran awal mengenai upaya pengolahan limbah rumah tangga sebagai solusi yang tepat dalam menumbuhkan bahkan meningkatkan kepedulian lingkungan siswa. Hal ini sejalan dengan pendapat Kose et al (2011) bahwa pembelajaran yang dikaitkan dengan sikap peduli lingkungan secara berangsur-angsur dapat mengubah sikap siswa agar lebih positif terhadap sampah.

Pelatihan pengolahan limbah rumah tangga megikutsertakan siswa/i MTs. Haudhul Ulum dalam praktiknya. Hal tersebut dimaksudkan agar siswa dapat membentuk kemandirian dalam melakukan suatu hal tertentu, seperti yang disajikan pada Gambar 3. Sebelum mengerjakan secara mandiri, siswa terlebih dahulu dibimbing untuk mempraktikkan langkah-langkah pembuatan POC secara sistematis, mulai dari pemilihan bahan, pengukuran bahan, hingga menghasilkan suatu produk yakni POC. Selama pelaksanaan kegiatan, banyak siswa yang merasa antusias dan semangat, bahkan ingin membuat pupuk sendiri menggunakan bahan selain yang dipraktikkan.

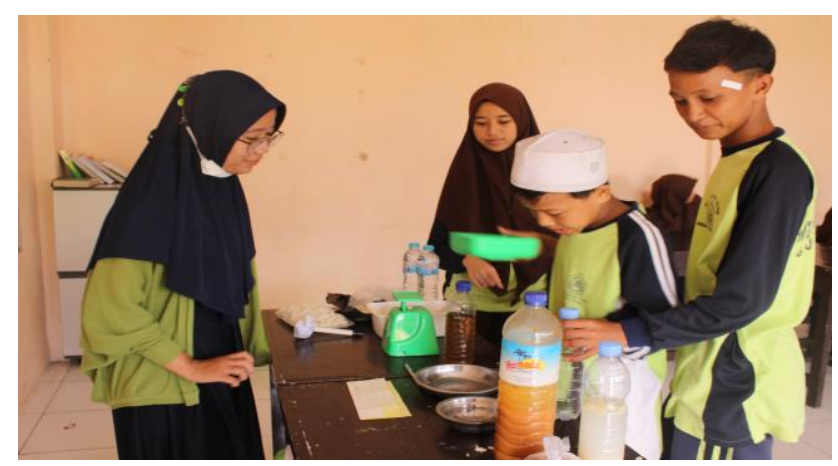




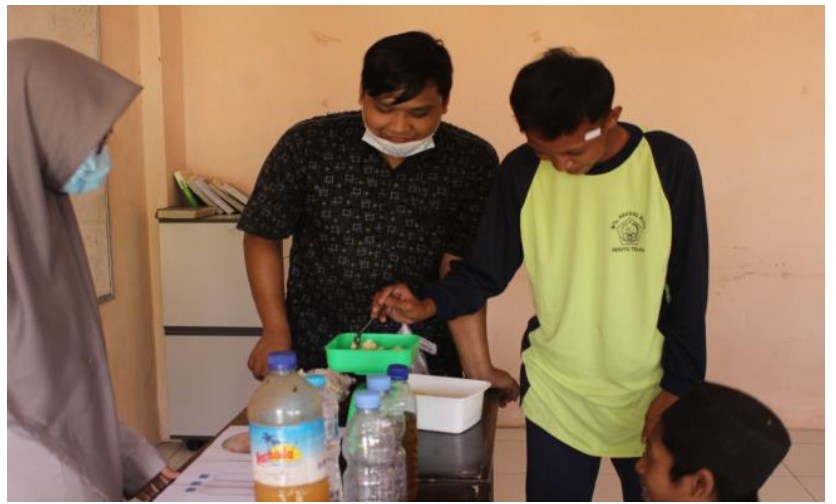

Gambar 3. Partisipasi siswa dan siswi selama pelatihan

\section{Hasil Produk Pupuk Organik Cair (POC) oleh siswa/i MTs. Haudhul Ulum}

Hasil produk pembuatan POC oleh siswa/i MTs. Haudhul Ulum dan bentuk POC yang sudah difermentasikan disajikan pada Gambar 4.

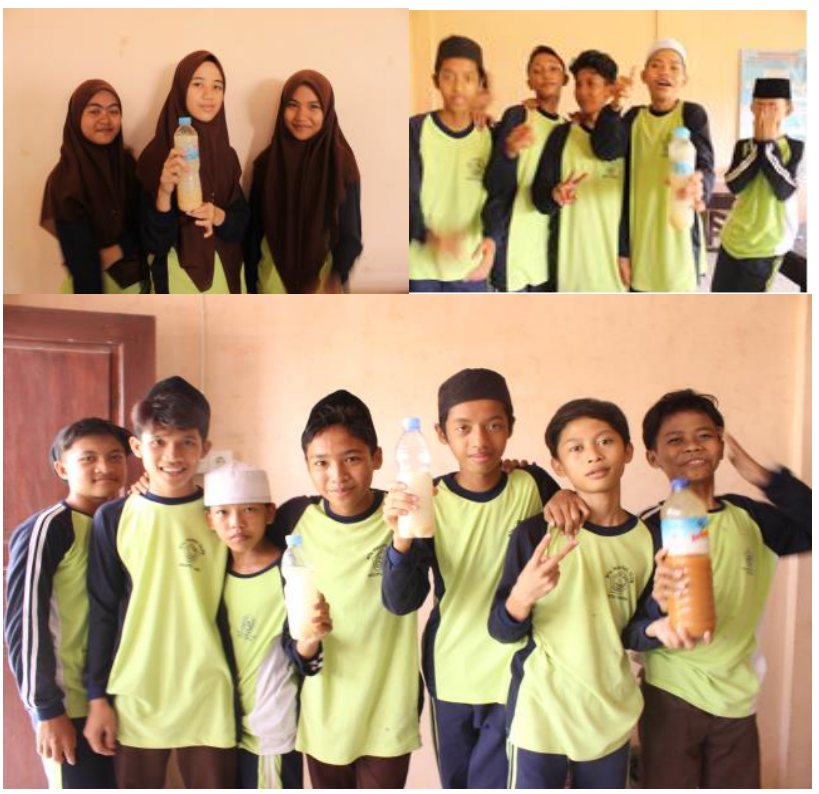

Gambar 4. Hasil produk POC oleh siswa dan siswi MTs. Haudhul Ulum

Berdasarkan Gambar 4 di atas, pembentukan MOL yang berhasil dan siap digunakan ditandai dengan adanya aroma yang dihasilkan akan berbau asam seperti tapai (Mulyono, 2016). Bau asam tersebut merupakan hasil dari fermentasi yang menghasilkan asam organik (Rahmah et al, 2014). Warna pada MOL yang dihasilkan putih keruh, karena dipengaruhi oleh bahan-bahan yang digunakan (Sunarsih, 2018). Larutan gula dan nasi basi merupakan bahan utama yang berfungsi sebagai nutrisi untuk mikroorganisme yang tumbuh di dalam larutan MOL, yang dimana nasi basi berperan sebagai sumber mikroorganisme dan penyedia suplemen seperti protein, karbohidrat, serat dan vitamin (Prasetyo et al, 2012). Dengan demikian, keuntungan yang didapat dalam menggunakan pupuk organik cair sebagai nutrisi tanaman yaitu mendukung budidaya tamanan yang ramah lingkungan, dapat mengatasi permasalahan pencemaran limbah rumah tangga dan limbah pertanian yang biasanya menggunakan pupuk kimia, pembuatan serta aplikasinya mudah dilakukan, memperkaya keberagaman biota tanah dan dapat memperbaiki kualitas tanah dan tanaman (Selviana, 2019).

\section{Kesimpulan}

Peduli lingkungan merupakan suatu sikap dan perilaku yang harus ditanamkan sejak dini kepada siswa melalui pendidikan karakter di sekolah. Pentingnya menumbuhkan sikap dan perilaku peduli lingkungan akan membentuk pribadi yang bertanggung jawab dan mandiri bagi dirinya dan juga lingkungan sekitar. Melalui kegiatan pengelolaan limbah rumah tangga menjadi POC, diketahui siswa/i MTs. Haudhul Ulum memiliki sikap peduli lingkungan yang baik $(89,5)$ dan perilaku peduli lingkungan yang cukup baik $(72,9)$. Dengan demikian, dapat disimpulkan bahwa dengan memberikan edukasi dan pelatihan kepada siswa mengenai cara mengolah sampah dengan bijak dapat menumbuhkan bahkan meningkatkan sikap dan perilaku peduli lingkungan.

\section{Ucapan Terima Kasih}

Terima kasih kepada Dosen Mata Kuliah Studi Mandiri Dr. Abdul Syukur, M.Si dan Dr. Jamaluddin, M.Pd yang telah membimbing kami dalam proses pelaksanaan penyusunan paper dari hasil kegiatan pengabdian di MTs Haudhul Ulum, Gegutu Telaga, Midang, Kecamatan Gunung Sari, Kab. Lombok Barat. Selanjutnya kepada Bapak Kepala MTs. Haudhul Ulum atas segala bimbingannya dan pihak-pihak yang terkait lainnya yang senantiasa selalu memberikan dukungan dalam terlaksananya kegiatan pengabdian ini. 


\section{Daftar Pustaka}

Arifan, F., Setyati, W. A., Broto, W., \& Dewi, A. L. (2020). Pemanfaatan Nasi Basi Sebagai Mikro Organisme Lokal (MOL) Untuk Pembuatan Pupuk Cair Organik di Desa Mendongan Kecamatan Sumowono Kabupaten Semarang. Jurnal Pengabdian Vokasi, 1(4), 252-255.

Kochakinezhad, H., Gh. Peyvast, A. K. Kashi, J.A. Olfati,danA. Asadii. (2012). A comparison of organik and chemical fertilizers for tomato production. $J$. Organik System, 7(2): 14-25.

Köse, S., Gencer, A. S., Gezer, K., Erol, G., \& Bilen, K. (2011). Investigation of undergraduate students' environmental attitudes. International Electronic Journal of environmental education, 1(2).

Masluki, M., Naim, M., \& Mutmainnah, M. (2016). Pemanfaatan Pupuk Organik Cair (POC) Pada Lahan Sawah Melalui Sistem Mina Padi. Prosiding, 2(1).

Mulyono. (2016). Membuat Mikroorganisme Lokal $(M O L)$ \& Kompos dari Sampah Rumah Tangga. AgroMedia Pustaka, Jakarta.

Nisa, K. (2016). Memproduksi Kompos dan Mikro Organisme Lokal (MOL). Bibit Publisher, Depok.

Prasetyo, M. N., Sari, N., \& Budiyati, C. S. (2012). Pembuatan Kecap Dari Ikan Gabus Secara Hidrolisis Enzimatis Mengunakan Sari Nanas. Jurnal Teknologi Kimia dan Industri, 1(1), 270-276.

Prasetyo, M. N., Sari, N., \& Budiyati, C. S. (2012). Pembuatan Kecap Dari Ikan Gabus Secara Hidrolisis Enzimatis Mengunakan Sari Nanas. Jurnal Teknologi Kimia dan Industri, 1(1), 270-276.

Purwanti, D. (2017). Pendidikan Karakter Peduli Lingkungan dan Implementasinya. DWIJA CENDEKIA: Jurnal Riset Pedagogik, 1(2).

Rahmah, A., Izzati, M., \& Parman, S. (2014). Pengaruh pupuk organik cair berbahan dasar limbah sawi putih (Brassica Chinensis L.) terhadap pertumbuhan tanaman jagung manis (Zea Mays L. Var.
Saccharata). Anatomi Fisiologi, 22(1), 6571.

Rahmah, A., Izzati, M., \& Parman, S. (2014). Pengaruh pupuk organik cair berbahan dasar limbah sawi putih (Brassica Chinensis L.) terhadap pertumbuhan tanaman jagung manis (Zea Mays L. Var. Saccharata). Anatomi Fisiologi, 22(1), 6571.

Selviana, T. E. (2019). Pengolahan Limbah Nasi Basi menjadi Pupuk Organik Cair Mikroorganisme Lokal (MOL) bagi Tanaman.

Sunarsih, L. E. (2018). Penanggulangan Limbah. Yogyakarta: Deepublish. 